\title{
PENERAPAN ASAS DOMINIS LITIS BAGI HAKIM DALAM MEMUTUS SENGKETA TATA USAHA NEGARA DI PENGADILAN TATA USAHA NEGARA PEKANBARU
}

\section{Raja Pangihutan Hasibuan}

Program Studi IImu Hukum pada Fakultas Syariah dan Hukum, Universitas Islam Negeri Sultan Syarif Kasim Riau, Jl. HR. Soebrantas KM. 15 Simpang Panam

\begin{abstract}
Application of the principle of activeness of judges (domitis litis principle) in the pekanbaru state Administrative court at the prooft stage has not yet proceeded according to law number 5 of 1986 concerning state Administrativecourt due to incomplete understanding of the principle of ultra petita, which is a consequence of the principle of activeness of judges (the principle of litis dominis0. This can be seen from case number ; 18/G/2014/PTUN-Pbr., and case number ; 24/G/2014/PTUN-Pbr. Obstacles in the application of the Judicial acts principle (principle of domiticlitis) in the pekanbaru State Administrative court include; theoretical constraints, namely constraints arising from the influence of affirmative proof system theory, which means strengthening or authorizing, juridical constaints, namely obstacles arising from the formulation of regulations governing regarding the principle of activeness of judges in staturory regulations, and operational constrain that arise in the implementation of proceedungs in court.
\end{abstract}

Keywords: asas dominis litis, state administration 


\begin{abstract}
Abstrak
Penerapan asas keaktifan hakim (asas dominis litis) di Pengadilan Tata Usaha Negara Pekanbaru pada tahap pembuktian belum berjalan sesuai Undang-Undang Nomor 5 Tahun 1986 tentang Peradilan Tata Usaha Negara karena belum lengkapnya pemahaman mengenai asas ultra petita, yang merupakan konsekuensi dari asas keaktifan hakim (asas dominis litis). Hal tersebut dapat dilihat dari Perkara Nomor : 18/G/2014/PTUN-Pbr., dan Perkara Nomor : 24/G/2014/PTUN-Pbr. Hambatan dalam penerapan Asas Keaktifan Hakim (Asas Dominis Litis) di Pengadilan Tata Usaha Negara Pekanbaru meliputi : kendala yang bersifat teoritis yaitu kendala yang timbul dari pengaruh teori sistem pembuktian afirmatif yang berarti menguatkan atau mengesahkan, kendala yuridis yaitu kendala yang timbul akibat perumusan ketentuan yang mengatur mengenai asas keaktifan hakim dalam peraturan perundang-undangan, dan kendala-kendala yang bersifat operasional yaitu yang timbul dalam pelaksanaan beracara di Pengadilan.
\end{abstract}

\title{
Keywords: asas dominis litis, Tata Usaha Negara
}

\section{Pendahuluan}

Pemeriksaan sengketa tata usaha negara seharusnya disesuaikan dengan sifat sengketa tata usaha negara yang ditimbulkan oleh Keputusan Tata Usaha Negara. Keputusan Tata Usaha Negara merupakan hasil perbuatan hukum publik sepihak (eenzijdige publiekrechtelijk handeling) dari badan atau pejabat tata usaha negara.

Seperti telah diuraikan diatas, Penjelasan Umum angka (5) Undang-Undang Nomor 5 Tahun 1986 menyatakan bahwa hukum acara yang digunakan pada Peradilan Tata Usaha Negara mempunyai persamaan dengan hukum acara yang digunakan pada Peradilan Umum untuk perkara perdata.

Sebagai suatu perbandingan, menurut Sudikno bahwa salah satu prinsip dalam pembuktian menyatakan bahwa pembagian beban 
pembuktian itu baru dirasakan adil dan tepat apabila yang dibebani pembuktian itu adalah pihak yang paling sedikit dirugikan jika disuruh membuktikan. ${ }^{1}$

\section{Pengertian Peradilan Tata Usaha Negara}

Sudikno mengatakan bahwa Peradilan adalah segala sesuatu yang bertalian dengan tugas hakim dalam memutus perkara. Hal itu sesuai dengan kata dasar peradilan, yang terdiri dari kata adil dan mendapatkan awalan per dan akhiran an, yang berarti segala sesuatu yang bertalian dengan pengadilan. Pengadilan di sini bukanlah diartikan semata-mata sebagai badan untuk mengadili, melainkan juga memiliki pengertian yang abstrak, yaitu hal memberikan keadilan.

Riawan Tjandra mendefinisikan bahwa istilah Peradilan Tata Usaha Negara dapat didefinisikan sebagai keseluruhan proses atau aktivitas hakim tata usaha negara yang didukung oleh seluruh fungsionaris pengadilan dalam melaksanakan fungsi mengadili baik di Pengadilan Tata Usaha Negara, Pengadilan Tinggi Tata Usaha Negara maupun di Mahkamah Agung. Istilah Pengadilan dapat didefinisikan sebagai lembaga yang melaksanakan peradilan. ${ }^{2}$

Prajudi Atmosudirjo mendefinisikan Peradilan Administrasi Negara adalah setiap bentuk penyelesaian dari suatu perbuatan (pejabat, instansi) Administrasi Negara yang dipersoalkan oleh warga masyarakat, instansi masyarakat (perusahaan, yayasan, perhimpunan, dan sebagainya) atau sesama instansi pemerintah. ${ }^{3}$

Dalam simposium Peradilan Tata Usaha Negara pada kesimpulannya dijelaskan bahwa "Peradilan Semu (administratieve beroep) belum menjamin proses yudisiil yang murni dan obyektif,

${ }^{1}$ Sudikno Mertokusumo, Penemuan Hukum - Sebuah Pengantar, (Yogyakarta: Liberty,2000), hlm.135.

${ }^{2}$ Riawan Tjandra, Peradilan Tata Usaha Negara Mendorong Terwujudnya Pemerintahan Yang Bersih dan Berwibawa, (Yogyakarta : Liberty, 2009),hlm. 15. hlm. 21

${ }^{3}$ Prajudi Atmosudirjo, Administrasi Negara, (JakartaGhalia Indonesia, 1994), 
mengingat hal itu masih berlangsung dalam susunan pejabat eksekutif, dan oleh karena itu pula maka administratieve beroep belum merupakan Peradilan Tata Usaha Negara yang sesungguhnya." Dalam penelitian ini Peradilan Tata Usaha Negara yang dimaksud adalah Peradilan Administrasi Murni yang diselenggarakan langsung oleh Pengadilan Tata Usaha Negara.

Dengan demikian, sebagai perwujudan konsep negara hukum Peradilan Tata Usaha Negara mempunyai peranan yang menonjol, yaitu sebagai lembaga pengawas (kontrol) terhadap jalannya fungsi eksekutif, lebih khusus lagi terhadap tindakan Pejabat Tata Usaha Negara supaya tetap berada dalam koridor aturan hukum. Sementara, disisi lainnya ia sebagai wadah untuk melindungi hak individu dan warga masyarakat dari perbuatan melanggar hukum yang dilakukan oleh Pejabat Tata Usaha Negara. ${ }^{4}$

\section{Pengertian Gugatan dan Pejabat Tata Usaha Negara.}

\section{a. Gugatan Tata Usaha Negara.}

Dalam Pasal 1 angka 11 Undang-Undang Nomor 51 Tahun 2009 tentang Perubahan Kedua Atas Undang-Undang Nomor 5 Tahun 1986 tentang Peradilan Tata Usaha Negara diuraikan bahwa Gugatan adalah permohonan yang berisi tuntutan terhadap badan atau pejabat tata usaha negara dan diajukan ke pengadilan untuk mendapatkan putusan. ${ }^{5}$

Gugatan ke Pengadilan Tata Usaha Negara dapat dilakukan oleh Orang atau Badan Hukum Perdata seperti yang diuraikan dalam Pasal 53 ayat (1) Undang-Undang Nomor 9 Tahun 2004 yaitu Orang atau Badan Hukum Perdata yang merasa kepentingannya dirugikan oleh suatu Keputusan Tata Usaha Negara dapat mengajukan gugatan tertulis kepada pengadilan yang berwenang yang berisi tuntutan agar

${ }^{5}$ Lihat Pasal 1 angka 11 Undang-Undang Nomor 51 Tahun 2009 tentang Peradilan Tata Usaha Negara. 
Keputusan Tata Usaha Negara yang disengketakan itu dinyatakan batal atau tidak sah, dengan atau tanpa disertai tuntutan ganti rugi dan atau rehabilitasi. ${ }^{6}$

Dalam pengajuan gugatan juga dapat dilakukan dengan beberapa alasan. Saat sebelum perubahan Undang-Undang Nomor 5 Tahun 1986. Ada tiga alasan untuk dapat menggugat yang diuraikan dalam Pasal 53 ayat (2) yaitu : ${ }^{7}$

a. Keputusan Tata Usaha Negara yang digugat itu bertentangan dengan Peraturan Perundang-undangan yang berlaku;

b. Badan atau Pejabat Tata Usaha Negara pada waktu mengeluarkan keputusan sebagaimana dimaksud dalam ayat (1) telah menggunakan wewenangannya untuk tujuan lain dari maksud diberikannya wewenang tersebut.

c. Badan atau Pejabat Tata Usaha Negara pada waktu mengeluarkan atau tidak mengeluarkan keputusan sebagaimana dimaksud dalam ayat (1) setelah mempertimbangkan semua kepentingan yang tersangkut dengan keputusan itu seharusnya tidak sampai pada pengambilan atau tidak pengambilan keputusan tersebut.

Mengenai alasan gugatan ini, Philipus M. Hadjon mengatakan bahwa alasan menggugat pada dasarnya adalah persoalan keabsahan (rechtsmatigheid) dari suatu Keputusan Tata Usaha Negara. Keabsahan itu menyangkut wewenang, prosedur dan substansial. ${ }^{8}$ Tiga hal tersebut diukur dengan peraturan tertulis dan/atau Azas-Azas Umum Pemerintahan Yang Baik (AAUPB). Dengan demikian sebetulnya alasan menggugat cukup dua yaitu :

${ }^{6}$ Lihat Pasal 53 ayat (1) Undang-Undang Nomor 9 Tahun 2004 tentang Perubahan Atas Undan-Undang Nomor 5 Tahun 1986 tentang Peradilan Tata Usaha Negara

${ }^{7}$ Lihat Pasal 53 ayat (2) Undang-Undang Nomor 9 Tahun 2004 tentang Perubahan Atas Undan-Undang Nomor 5 Tahun 1986 tentang Peradilan Tata Usaha Negara 
a. Keputusan Tata Usaha Negara tersebut bertentangan dengan peraturan perundang-undangan;

b. Keputusan Tata Usaha Negara tersebut bertentangan dengan Azas-Azas Umum Pemerintahan Yang Baik (AAUPB) (rumusan Pasal 53 ayat (2) tidak logis).

Setelah diadakan perubahan atas Undang-Undang Nomor 5 Tahun 1986, maka ada dua alasan pokok untuk menggugat suatu Keputusan Tata Usaha Negara ke Pengadilan Tata Usaha Negara sebagaimana diatur dalam Pasal 53 ayat (2) Undang-Undang Nomor 9 Tahun 2004, dimana alasan-alasan yang dapat digunakan dalam gugatan sebagaimana dimaksud pada ayat (1) yaitu :

a. Keputusan Tata Usaha Negara yang digugat itu bertentangan dengan peraturan perundang-undangan yang berlaku;

b. Keputusan Tata Usaha Negara yang digugat itu bertentangan dengan Azas-Azas Umum Pemerintahan yang Baik.

Azas-Azas Umum Pemerintahan yang Baik, setelah adanya revisi Undang-Undang Nomor 5 Tahun 1986 telah diakui sebagai salah satu alasan untuk menggugat di Pengadilan Tata Usaha Negara. Didalam Penjelasan Pasal 53 ayat (2) Undang-Undang Nomor 9 Tahun 2004 dan juga sebagaimana diatur dalam Pasal 3 Undang-Undang Nomor 28 Tahun 1999 tentang Penyelenggaraan Negara yang Bersih dan Bebas dari Korupsi, Kolusi dan Nepotisme, dapat diketahui bahwa Azas-Azas Umum Pemerintahan yang Baik tersebut meliputi : 9

1. Azas Kepastian

2. Azas Tertib Penyelenggaraan Negara;

3. Azas Kepentingan Umum

4. Azas Keterbukaan;

5. Azas Proporsionalitas;

9 Lihat Pasal 3 Undang-Undang Nomor 28 Tahun 1999 tentang Penyelenggaraan Negara Yang Bersih dan Bebas dari Korupsi, Kolusi dan Nepotisme 
6. Azas Profesionalitas; dan

7. Azas Akuntabilitas.

8. Azas Praduga Rechtmatig (Prasumptio lustae Causa)

Keputusan yang dikeluarkan oleh badan atau pejabat tata usaha negara, Bagaimanapun cacatnya suatu keputusan, misalnya ada keputusan tanpa dasar hukum (sine lege), tetap harus dianggap sah dan berlaku sampai dinyatakan tidak sah oleh instansi yang berwenang (dalam hal ini Pengadilan Tata Usaha Negara).

Gugatan ke Pengadilan Tata Usaha Negara sebagaimana ketentuan Pasal 55 Undang-Undang Nomor 5 Tahun 1986 tentang Peradilan Tata Usaha Negara, hanya dapat diajukan dalam tenggang waktu 90 (sembilan puluh) hari. Ada 4 syarat dalam menentukan sejak kapan dapat mengajukan gugatan di Pengadilan Tata Usaha Negara yaitu : ${ }^{10}$

1. sejak diterima,

2. diumumkan,

3. diterbitkan dan,

4. diketahuinya keputusan badan atau pejabat tata usaha negara.

Gugatan yang diajukan, hendaknya memenuhi syarat yang telah diuraikan dalam Pasal 56 Undang-Undang Nomor 5 Tahun 1986 tentang Peradilan Tata Usaha Negara yaitu: ${ }^{11}$

1. Gugatan harus memuat:

a. nama, kewarganegaraan, tempat tinggal, dan pekerjaan penggugat atau kuasa nya;

b. nama jabatan, dan tempat kedudukan tergugat;

c. dasar gugatan dan hal yang diminta diputuskan oleh pengadilan.

${ }^{10}$ Lihat Pasal 55 Undang-Undang Nomor 5 Tahun 1986 tentang Peradilan Tata Usaha Negara

${ }^{11}$ Lihat Pasal 56 Undang-Undang Nomor 5 Tahun 1986 tentang Peradilan Tata 
2. apabila gugatan dibuat dan ditandatangani oleh seorang kuasa penggugat, maka gugatan harus disertai surat kuasa yang sah;

3. gugatan sedapat mungkin juga disertai keputusan tata usaha negara yang disengketakan oleh penggugat.

Menurut Martiman Prodjohamidjojo bahwa dalam Pasal 56 ayat (1) Undang-Undang tersebut memberikan petunjuk mengenai isi surat gugatan dan menetapkan adanya dua syarat yang wajib dipenuhi yaitu:

1) Syarat formil memuat: ${ }^{12}$

a. nama, kewarganegaraan, tempat tinggal, dan pekerjaan penggugat maupun kuasanya;

b. nama jabatan, dan tempat kedudukan tergugat;

2) Syarat materil meliputi:

a. dasar gugatan yaitu kejadian-kejadian atau hal-hal yang merupakan dasar tuntutan, jadi merupakan alasan adanya tuntutan itu (posita atau fundamentum petendi);

b. tuntutan yaitu apa yang dituntut berupa tuntutan pokok dan tuntutan ganti rugi dan/atau rehabilitasi.

Tidak setiap orang dapat bertindak sendiri untuk membela hakhaknya, dalam hal demikian ia dapat didampingi oleh kuasa. Pasal 56 ayat (2) tersebut memberikan kesempatan yang seluas-luasnya kepada setiap orang untuk memberikan kuasa dalam pembelaan haknya atau kepentingannya itu.

\section{b. Pejabat Tata Usaha Negara}

Rumusan Pejabat Tata Usaha Negara dapat ditelaah dari dua sudut, yaitu :

1. Perundang-undangan, Pengertian Pejabat Tata Usaha Negara berdasarkan peraturan perundang-undangan adalah badan atau seseorang jika dalam melakukan tugas kewajibannya sebagai

\footnotetext{
${ }^{12}$ Martiman Prodjohamidjojo, Hukum Acara Pengadilan Tata Usaha Negara dan Undang-Undang Nomor 9 Tahun 2004, (Jakarta : Ghalia Indonesia, 2005), hlm. 50-51.
} 
aparatur negara didasarkan pada ketentuan yang berlaku. Dalam hal ini ketentuan-ketentuan yang merupakan landasan kewenangan pejabat tata usaha negara.

2. Keputusan Pejabat Tata Usaha Negara, adalah jika kewenangan pejabat ada atau diadakan untuk menata hidup bersama, termasuk menyelesaikan persoalan-persoalan yang ia hadapi, tetapi hukum yang mengatur dan/atau menyelesaikan persoalanpersoalan itu tidak ada maka ia berwenang untuk mengambil keputusan dalam rangka kebijaksanaan tertinggi (top administrator). ${ }^{13}$

\section{Obyek dan Subyek Sengketa Tata Usaha Negara}

\section{a. Obyek Sengketa Tata Usaha Negara}

Adapun obyek dalam Sengketa Tata Usaha Negara telah diatur dalam Pasal 1 angka 9 Undang-Undang Nomor 51 Tahun 2009 tentang Perubahan Kedua Atas Undang-Undang Nomor 5 Tahun 1986 tentang Peradilan Tata Usaha Negara yang menyatakan bahwa Keputusan Tata Usaha Negara adalah suatu penetapan tertulis yang dikeluarkan oleh Badan atau Pejabat Tata Usaha Negara yang berisi tindakan tata usaha negara berdasarkan peraturan perundang-undangan yang berlaku, yang bersifat konkret, individual dan final, yang menimbulkan akibat bagi seseorang atau badan hukum perdata. ${ }^{14}$

Menurut Indroharto bahwa unsur-unsur penetapan tertulis/beschikking terdiri dari :Bentuk penetapan itu harus tertulis, dikeluarkan oleh badan atau jabatan tata usaha negara, berisi tindakan tata usaha negara, berdasarkan peraturan perundang-undangan yang berlaku, bersifat konkret, individual

\footnotetext{
${ }^{13}$ Ibid., hlm. 31.

${ }^{14}$ Lihat Pasal 1 angka 9 Undang-Undang Nomor 5 Tahun 1986 tentang Peradilan Tata Usaha Negara
} 
dan final, menimbulkan akibat bagi seseorangatau badan perdata.

Keputusan Administratif merupakan suatu pengertian yang sangat umum dan abstrak, yang dalam praktek tampak dalam bentuk keputusan yang amat berbeda. Namun mempunyai ciri-ciri yang sama, karena akhirnya dalam teori hanya ada suatu pengertian keputusan administratif. Keputusan tersebut ada yang fiktif dan positif, dalam kaitannya dengan kajian ini keputusan tersebut bentuknya tidak tertulis. Berkenaan kaitannya dengan Sengketa Tata Usaha Negara, apabila pemohon merasa dirugikan oleh Badan atau Pejabat Tata Usaha Negara yang berwenang dengan adanya keputusan yang tidak tertulis itu maka ia dapat menggugat pejabat yang berwenang itu di depan Pengadilan Tata Usaha Negara, dengan objek sengketanya adalah keputusan tidak tertulis itu (atau keputusan fiktif dan negatif). ${ }^{15}$

Keputusan Tata Usaha Negara tidak semuanya dapat digugat pada Peradilan Tata Usaha Negara, dimana hal ini dapat dilihat dalam Pasal 2 Undang-Undang Nomor 5 Tahun 1986 tentang Peradilan Tata Usaha Negara yang mengatur bahwa tidak termasuk dalam pengertian Keputusan Tata Usaha Negara menurut Undang-Undang ini adalah : ${ }^{16}$

a. Keputusan Tata Usaha Negara yang merupakan perbuatan perdata;

b. Keputusan Tata Usaha Negara yang merupakan pengaturan yang bersifat umum;

c. Keputusan Tata Usaha Negara yang masih memerlukan persetujuan;

${ }^{15}$ Jurnal Mahkamah, Edisi 11, Oktober 1996, M. Husnu Abadi, Keputusan Tidak Tertulis Sebagai Objek Sengketa Pada Peradilan Tata Usaha Negara, hlm 13-27. Usaha Negara

${ }^{16}$ Lihat Pasal 2 Undang-Undang Nomor 5 Tahun 1986 tentang Peradilan Tata 
d. Keputusan Tata Usaha Negara yang dikeluarkan berdasarkan ketentuan Kitab Undang-Undang Pidana dan Kitab Undang-Undang Acara Pidana atau Peraturan Perundang-undangan lain yang bersifat pidana;

e. Keputusan Tata Usaha Negara yang dikeluarkan atas dasar hasil pemeriksaan badan peradilan berdasarkan ketentuan peraturan perundang-undangan yang berlaku;

f. Keputusan Tata Usaha Negara mengenai tata usaha Tentara Nasional Indonesia;

g. Keputusan Komisi Pemilihan Umum, baik di pusat maupun di daerah mengenai hasil pemilihan umum.

Dalam Pasal3 Undang-Undang Nomor 5 Tahun 1986 tentang Peradilan Tata Usaha Negara disebutkan mengenai hal yang juga dapat dikategorikan sebagai Keputusan Tata Usaha Negara, yaitu : ${ }^{17}$

a. Apabila badan atau pejabat tata usaha negara tidak mengeluarkan keputusan, sedangkan hal itu menjadi kewajibannya, maka hal tersebut disamakan dengan Keputusan Tata Usaha Negara.

b. Jika suatu badan atau pejabat tata usaha negara tidak mengeluarkan keputusan yang dimohon, sedangkan jangka waktu sebagaimana ditentukan dalam peraturan perundang-undangan dimaksud lewat, maka Badan atau Pejabat Tata Usaha Negara tersebut dianggap telah menolak mengeluarkan keputusan yang dimaksud.

${ }^{17}$ Lihat Pasal 3 Undang-Undang Nomor 3 Tahun 1986 tentang Peradilan Tata 
c. Dalam peraturan perundang-undangan yang bersangkutan tidak menentukan jangka waktu sebagaimana dimaksud dalam ayat (2), maka setelah lewat jangka waktu empat bulan sejak diterimanya permohonan, Badan atau Pejabat Tata Usaha Negara yang bersangkutan dianggap telah mengeluarkan keputusan penolakan.

Kompetensi Absolut dari Peradilan Tata Usaha Negara berarti hanya penetapan tertulis yang dikeluarkan oleh Badan/Pejabat Tata Usaha Negara yang bersifat konkrit, individual dan final sajalah yang dapat digugat, apabila penetapan tersebut hanya bersifat final dan konkrit, akan tetapi tidak ditujukan pada orang tertentu atau hanya secara umum saja, maka tidak dapat diajukan ke Pengadilan Tata Usaha Negara.

\section{b. Subyek Sengketa Tata Usaha Negara}

Pada umumnya dalam sengketa di Pengadilan, selalu ada pihak-pihak yang berperkara, begitu pula di bidang administrasi negara, ada dua subyek yang bersengketa, lazimnya disebut sebagai Penggugat dan Tergugat.

Mengenai siapa yang berhak menggugat atau pihak Penggugat dapat dilihat dalam Pasal 53 ayat (1) UndangUndang Nomor 5 Tahun 1986 sebagaimana diubah dengan Undang-Undang Nomor 9 Tahun 2004 yaitu :Orang atau Badan Hukum Perdata yang merasa kepentingannya dirugikan oleh suatu Keputusan Tata Usaha Negara dapat mengajukan gugatan tertulis kepada Pengadilan yang berwenang yang berisi tuntutan agar Keputusan Tata Usaha Negara yang disengketakan itu dinyatakan batal atau tidak sah, dengan atau tanpa disertai tuntutan ganti rugi dan/atau direhabilitasi. 
Penggugat disini adalah orang atau Badan Hukum Perdata yang dirugikan atas dikeluarkannya Keputusan Tata Usaha Negara. ${ }^{18}$

Mengenai Penggugat ini Indroharto berpendapat bahwaPenggugat adalah Orang atau Badan Hukum Perdata yang dirugikan akibat dikeluarkan Keputusan Tata Usaha Negara pada dasarnya digolongkan dalam tiga kelompok: ${ }^{19}$

\section{c. Kewenangan Badan atau Pejabat Tata Usaha Negara}

Wewenang didefinisikan sebagai kekuasaan membuat keputusan, memerintah, dan melimpahkan tanggung jawab kepada orang lain; fungsi yang boleh tidak dilaksanakan. Kewenangan atau wewenang dalam literatur berbahasa Inggris disebut authority atau competence, sedang dalam bahasa Belanda disebut gezag atau bevoegdheid. Wewenang adalah kemampuan untuk melakukan suatu tindakan hukum publik atau kemampuan bertindak yang diberikan oleh undang-undang yang berlaku untuk melakukan hubungan-hubungan hukum. ${ }^{20}$

Kewenangan adalah kekuasaan yang mendapatkan keabsahan atau legitimasi kewenangan adalah hak moral untuk membuat dan melaksanakan keputusan politik prinsip moral menentukan siapa yang berhak memerintah/mengatur cara dan prosedur melaksanakan wewenang. Sebuah bangsa atau negara mempunyai tujuan. Kegiatan untuk mencapai tujuan disebut tugas hak moral untuk melakukan kegiatan mencapai tujuan disebut kewenangan. Tugas dan kewenangan untuk mencapai tujuan masyarakat atau negara disebut fungsi.

\section{Kompetensi Peradilan Tata Usaha Negara.}

\footnotetext{
${ }^{18}$ Lihat Pasal 53 ayat (1) Undang-Undang Nomor 5 Tahun 1986 tentang Peradilan Tata Usaha Negara

${ }^{19}$ Indroharto (I), Usaha Memahami Undang-Undang .......,Op. Cit., hlm. 17.

${ }^{20}$ Ruslan Effendi danDoddi Panjaitan. Ketidak Absahan Kewenangan Aparat Terhadap Produk Hukum Yang Dihasilkan. Lihat http://doddipanjaitan.blogspot.com /2011/04/ketidakabsahan-kewenangan-aparat.html.,diakses tanggal 01 April 2015.
} 
Peradilan Tata Usaha Negara hanya memiliki kompetensi untuk menguji keabsahan perbuatan tata usaha negara yang dilakukan oleh badan atau pejabat tata usaha negara yang diwujudkan oleh suatu keputusan tata usaha negara (beschikking).

Dalam Pasal 4 Undang-Undang Nomor 9 Tahun 2004 tentang Perubahan Atas Undang-Undang Nomor 5 Tahun 1986 tentang Peradilan Tata Usaha Negara disebutkan bahwa "Peradilan Tata Usaha Negara adalah salah satu pelaku kekuasaan kehakiman bagi rakyat pencari keadilan terhadap sengketa Tata Usaha Negara". ${ }^{21}$

Kompetensi (kewenangan) suatu badan pengadilan untuk mengadili suatu perkara dapat dibedakan atas kompetensi relatif dan kompetensi absolut. Kompetensi relatif berhubungan dengan kewenangan pengadilan untuk mengadili suatu perkara sesuai dengan wilayah hukumnya, sedangkan kompetensi absolut adalah kewenangan pengadilan untuk mengadili suatu perkara menurut obyek, materi atau pokok sengketa. ${ }^{22}$

1. Kompetensi Relatif

Kompetensi relatif suatu badan pengadilan ditentukan oleh batas daerah hukum yang menjadi kewenangannya. Suatu badan pengadilan dinyatakan berwenang untuk memeriksa suatu sengketa apabila salah satu pihak sedang bersengketa (Penggugat/Tergugat) berkediaman disalah satu daerah hukum yang menjadi wilayah hukum pengadilan itu. Untuk Pengadilan Tata Usaha Negara, kompetensi relatifnya diatur dalam Pasal 6 Undang-Undang Nomor 5 Tahun 1986 tentang Peradilan Tata Usaha Negara menyatakan: ${ }^{23}$

${ }^{21}$ Lihat Pasal 4 Undang-Undang Nomor 9 Tahun 2004 tentang Perubahan Atas Undang-Undang Nomor 5 Tahun 1986 tentang Peradilan Tata Usaha Negara

${ }^{22}$ S.F.Marbun, Peradilan Tata Usaha Negara, (Yogyakarta : Liberty, 2003),hlm. 59 Usaha Negara

${ }^{23}$ Lihat Pasal 6 Undang-Undang Nomor 5 Tahun 1986 tentang Peradilan Tata 
1. Pengadilan Tata Usaha Negara berkedudukan di ibukota Kabupaten/Kota, dan daerah hukumnya meliputi wilayah Kabupaten/Kota.

2. Pengadilan Tinggi Tata Usaha Negara berkedudukan di ibukota Provinsi dan daerah hukumnya meliputi wilayah Provinsi.

2. Kompetensi Absolut

Kompetensi Absolut suatu badan pengadilan adalah kewenangan yang berkaitan untuk mengadili suatu perkara menurut obyek atau materi atau pokok sengketa. Adapun yang menjadi obyek sengketa di Pengadilan Tata Usaha Negara adalah Keputusan Tata Usaha Negara (Beschikking) yang diterbitkan oleh Badan/Pejabat Tata Usaha Negara. Sebagaimana disebutkan dalam Pasal 1 angka 9 UndangUndang Nomor 51 Tahun 2009 tentang Perubahan Kedua Atas Undang-Undang Nomor 5 Tahun 1986 tentang Peradilan Tata Usaha Negara, sedangkan perbuatan Badan/Pejabat TUN lainnya baik perbuatan materiil (material daad) maupun penerbitan peraturan (regeling) masing-masing merupakan kewenangan Peradilan Umum dan Mahkamah Agung Kompetensi Absolut Pengadilan Tata Usaha Negara diatur dalam Pasal 1 angka 10 Undang-Undang Nomor 51 Tahun 2009 tentang Perubahan Kedua Atas Undang-Undang Nomor 5 Tahun 1986 tentang Peradilan Tata Usaha Negara, yang menyebutkan bahwaSengketa Tata Usaha Negara adalah sengketa yang timbul dalam bidang tata usaha negara antara orang atau badan hukum perdata dengan badan atau pejabat tata usaha negara, baik di pusat maupun di daerah, sebagai akibat dikeluarkannya keputusan tata usaha negara, termasuk 
sengketa kepegawaian berdasarkan peraturan perundangundangan yang berlaku. ${ }^{24}$

\section{E. Sikap Hakim Pengadilan Tata Usaha Negara}

Terdapat perbedaan antara hakim dalam Peradilan Umum dan Peradilan Tata Usaha Negara yang mana hakim pada Peradilan Tata Usaha Negara diberikan peran aktif dalam proses persidangan guna memperoleh kebenaran materiil dan mengarah pada ajaran pembuktian bebas. ${ }^{25}$

Hakim dalam peradilan tata usaha negara diberikan peran aktif karena hakim tidak mungkin membiarkan dan mempertahankan tetap berlakunya suatu keputusan administrasi negara yang nyata keliru dan jelas bertentangan dengan undang-undang yang berlaku, hanya karena alasan para pihak tidak mempersoalkannya dalam objek sengketa. $^{26}$

Berkaitan dengan sistem yang berlaku di negara kita, sebagaimana pada umumnya di negara-negara yang bersistem hukum civil law/Eropa Kontintetal, kita mengenal adanya metode penemuan hukum (rechtsvinding) yang dihasilkan dari kombinasi antara ilmu pengetahuan dan pengalaman hakim sebagai profesi (knowledge and experience). ${ }^{27}$

Manakala hakim menghadapi kasus-kasus konkret yang harus diadilinya, dimana hukum yang bersifat statis atau yang menimbulkan ketidakjelasan dalam masyarakat yang senantiasa berkembang dan lain sebagainya, maka diperlukan kemampuan berpikir pada hakim untuk mencari hukum dan menemukan hukum

\footnotetext{
${ }^{24}$ Lihat Pasal 1 angka 10 UU Nomor 51 Tahun 2009 tentang Perubahan Kedua Undang-Undang Nomor 5 Tahun 1986 Tentang Peradilan Tata Usaha Negara.

${ }^{25}$ W. Riawan Tjandra, S.H., M.Hum, Litis Domini Principle, (Yogyakarta : Universitas Atmajaya, 2004),hlm. 1

${ }^{26} \mathrm{Ibid}$., hlm. 2

${ }^{27}$ Paulus Effendi Lotulung, Lintasan Sejarah dan Gerak Dinamika Peradilan Tata Usaha Negara (Peratun), (Jakarta : Salemba Humanika, 2013), hlm. 101
} 
sebagai solusi dalam kasus yang dihadapinya yang harus dipecahkan dan diputuskan secara tepat dan adil. ${ }^{28}$

\section{F. Kesimpulan}

Berdasarkan hasil pembahasan yang telah diuraikan tersebut, maka disimpulkan sebagai berikut:

1. Penerapan asas keaktifan hakim (asas dominis litis)di Pengadilan Tata Usaha Negara Pekanbaru pada tahap pembuktian belum berjalan sesuai Undang-Undang Nomor 5 Tahun 1986 tentang Peradilan Tata Usaha Negara karena belum lengkapnya pemahaman mengenai asas ultra petita, yang merupakan konsekuensi dari asas keaktifan hakim (asas dominis litis). Hal tersebut dapat dilihat dari Perkara Nomor : 18/G/2014/PTUN-Pbr., dan Perkara Nomor : 24/G/2014/PTUN-Pbr.

Hambatan dalam penerapan Asas Keaktifan Hakim (Asas Dominis Litis)di Pengadilan Tata Usaha Negara Pekanbaru meliputi : kendala yang bersifat teoritis yaitu kendala yang timbul dari pengaruh teori sistem pembuktian afirmatif yang berarti menguatkan atau mengesahkan, kendala yuridis yaitu kendala yang timbul akibat perumusan ketentuan yang mengatur mengenai asas keaktifan hakim dalam peraturan perundang-undangan, dan kendala-kendala yang bersifat operasionalyaitu yang timbul dalam pelaksanaan beracara di Pengadilan Tata Usaha Negara yang disebabkan oleh belum lengkapnya yurisprudensi dalam sistem peradilan tata usaha negara sebagai pegangan dalam beracara dan perumusan dalil-dalil dalam sengketa tata usaha negara yang terkesan masih kurang bersifat kreatif serta membuat rancu dasar gugatan.

\footnotetext{
${ }^{28}$ Ibid.
} 


\section{DAFTAR PUSTAKA}

\section{A. Buku-Buku}

Indroharto (I). 1996. Usaha Memahami Undang-Undang tentang Peradilan

Tata Usaha Negara. Jakarta : Pustaka Sinar Harapan.

Paulus Effendi Lotulung. 2013. Hukum Tata Usaha Negara dan Kekuasaan. Jakarta : Salemba Humanika.

Philipus M. Hadjon, Dkk. 1997. Pengantar Administrasi Indonesia. Yogyakarta : Gadjah Mada University Press.

Prajudi Atmosudirjo. 1994. Administrasi Negara. Jakarta : Ghalia Indonesia.

Riawan Tjandra. 2009. Peradilan Tata Usaha Negara PTUN Mendorong Terwujudnya Pemerintahan yang Bersih dan Berwibawa. Yogyakarta : Liberty.

S.F Marbun, 1997. Peradilan Administrasi Negara dan Upaya Administrasi di Indonesia. Yogyakarta : Liberty.

Soerjono Soekanto. 1982. Pengantar Penelitian Hukum. Jakarta : UIPress

Subekti R. dan Tjitrosoedibio. 1971. Kamus Hukum. Jakarta : Pradnya Paramitha,

Sudikno Mertokusumo. 2000. Penemuan Hukum - Sebuah Pengantar. Yogyakarta : Liberty

W. Riawan Tjandra, S.H., M.Hum. 2004. Litis Domini Principle. Yogyakarta : Universitas Atmajaya

\section{B. Peraturan Perundang-Undangan}

Undang-Undang Nomor 14 Tahun 1985 tentang Mahkamah Agung Undang-Undang Nomor 5 Tahun 1986 tentang Peradilan Tata Usaha Negara.

Keputusan Presiden Nomor 2 Tahun 1997 tentang Pembentukan Pengadilan Tata Usaha Negara Banda Aceh, Pekanbaru, Jambi, 
Bengkulu, Palangkaraya, Palu, Kendari, Yogyakarta, Mataram dan

Dili

Undang-Undang Nomor 28 Tahun 1999 tentang Penyelenggaraan Negara

yang Bersih dan Bebas dari Korupsi, Kolusi dan Nepotisme

Undang-Undang Nomor 48 Tahun 2009 tentang Kekuasaan Kehakiman

Undang-Undang Nomor 51 Tahun 2009 tentang Perubahan Kedua Atas

Undang-Undang Nomor 5 Tahun 1986 tentang Peradilan Tata

Usaha Negara.

Keputusan Presiden Nomor 18 Tahun 2011 tentang Pembentukan

Pengadilan Tata Usaha Negara Kepulauan Riau dan Pengadilan

Tata Usaha Negara SerangUndang-Undang Dasar Negara Republik Indonesia Tahun 1945

\section{Artikel/Jurnal/Makalah}

Jurnal Mahkamah edisi 11 Oktober 1996. M. Husnu Abadi. Keputusan Tidak Tertulis Sebagai Objek Sengketa Pada PTUN.

Kadar Slamet. Mei 2009. "Subyek (Penggugat Dan Tergugat) Serta Perkembangan Subyek Dan Obyek Dalam Yurisprudensi TUN".

\section{Internet}

http://ptun-pekanbaru.go.id/. Ruslan Effendi dan Doddi Panjaitan, Ketidak Absahan Kewenangan Aparat Terhadap Produk Hukum Yang Dihasilkan.

http://doddipanjaitan.blogspot.com/2011/04/ketidakabsahankewe nangan-aparat.html. 